portions, I found a circular opening sufficiently large to admit a goose-quill, and with an extremely thin peritoneal edge, through which the contents of the intestines had escaped into the sac. On examining the orifice closely, it was observed to be seated in the centre of an old cicatrix of large size.

This appears to have been a case of pure atony, or rather of actual paralysis, of the muscular coats of the entire intestinal tube, from the stomach to the commencement of the rectum. It is a question how far the patient's inordinate habit of tobacco chewing and smoking may have tended to this remark. able impairment of muscular action. The rupture of the colon was evidently an accidental circumstance after violent straining, and would not, in all probability have occurred if the intestinal wall had been of uniform thickness.

Toronto, May, $185 \overline{5}$.

\section{ON A CASE OF ANEURISM OF THE AORTA.} By WALTER SUMPTER, M.D., Cley, Norfolk.

Mrs. R. S-_ of Blakeney, Norfolk, an anæmic-looking female, consulted me on May 16 th, as to the cause of a constant fluttering in the throat, accompanied by dyspncea, cough, and temporary aphonia. On inquiry I found that the patient had been ailing for two years, but felt much worse after a long fatiguing walk about nine months since, during which walk she felt a sharp pain in the chest, accompanied by a violent fit of coughing, which weakened her so much that she could scarcely crawl home. No expectoration of blood, however, took place. On making a physical examination of the thorax, a peculiar pulsation over the right sterno-clavicular region was evident, and on applying the stethoscope, the impulse was im parted to that instrument, jerking it forward with each systole of the ventricles. On applying the ear, the peculiar "whizzing" sound was heard, and aneurism of the aorta was evidently my diagnosis, and I considered it my duty to forewarn my patient's friends of her highly precarions state. I prescribed digitalis, combined with other sedative and laxative remedies, and enjoined absolute rest. I was several times summoned, as she was thought to be dying from the intense dyspncea that tem porarily existed; but she lingered on for several months, when a violent paroxysm of coughing closed the scene.

At the necropsy I discovered that the rupture of the aneurism had taken place within the pericardium. The heart was in a state of fatty degeneration, and much enlarged, weighing fifteen ounces.

The peculiar features in this case are the absence of hæmoptysis and pain, with no general disturbance of the circulation, and no rupture of the artery itself.

July, 1858.

ON A CASE OF

\section{PUNCTURED WOUND OF THE UPPER EYELID, PENETRATING DEEPLY INTO THE ORBIT.}

$$
\text { By GEORGE RUSSELL, EsQ., M.R.C.S. }
$$

$\mathbf{M}$ - , a little girl, aged seven, was brought to my surgery on the 1st of December last. On examination, I found a vertical wound on her forehead of about two inches in length, which terminated inferiorly in a punctured wound of the upper eyelid, immediately below the orbital ridge. From the wound in the eyelid protruded a mass of fat, cellular tissue, \&c., of the size of a nut. This I transfixed with a tenaculum, and sliced off. I adopted this course, as I foresaw great difficulty in returning it on account of the great resistance my young patient seemed determined to make, and $I$ was also afraid that if $I$ succeeded it would slough. I closed that part of the wound in the eyelid with a suture, and that on the forehead I brought to gether with a strap. With difficulty, owing to the swelling of the lid and the restlessness of the patient, I obtained a glimpse of the cornea, and it appeared to be uninjured. After the operation I ordered her to be placed in a bed with a very high pillow, in a darkened room, and a light fold of lint placed over the eye, which was to be kept damp with an evaporating lotion, 88 and to take three grains of calomel, followed by small doses of sulphate of magnesia every four hours. However, as no amount of coaxing would induce her to take the medicine, and being afraid to have recourse to harsh measures, lest she should struggle and cry, and so cause hæmorrhage in the orbit, I contented myself with employing darkness, cold applications, and spoon diet. A few hours afterwards I saw her again, when she appeared drowsy, and romited two or three times; pulse 80. T ordered her to be constantly attended, and kept in the same position, with the head and shoulders well elevated, and on the following morning the drowsiness and sickness had passed off, and she had slept comfortably for some hours.

The bowels were spontaneously evacuated on the fourth day. On the same day I took out the suture, and found the wound healed. Some time elapsed before she conld open her eye, owing to the swelling of the lid. This has now subsided, and her sight is perfect; but the eye seems more prominent than its fellow. There is slight ptosis and external strabismus; but I am in strong hopes that time will remedy these defects as a gradual improvement is quite apparent. Upon inspecting the instrument which caused the injury, I found it to be a rusty, blunt iron spike, fourteen inches in length and one inch and three quarters in circumference. This penetrated the orbit to the depth of two inches and a half. The accident occurred by the child pulling down upon herself a piece of timber in which the spike was fixed.

The above case shows what a slight amount of local or con stitutional irritation may occasionally follow a severe wound in so delicate a situation; and I am inclined to think that position, in cases of severe injuries of the head, is as well worthy of consideration as it is in treatment in those of the extremities. July, 1858 .

\section{de}

OF THE PRACTICE OF

\section{MEDICINE AND SURGERY IN THE}

\section{HOSPITALS OF LONDON.}

Nulla est alia pro certo noscendi via, nisi quam piurimas et morborum dissectionum historias, tam aliorum proprias, collectas habere et inter se com parare,-Morgagri. De Sed, et Caus. Morb.lib. 14. Procmium.

\section{UNIVERSITY COLLEGE HOSPITAL.}

\section{EXTEYSTVE DISEASE OF THE HIP-JOINT IN A GIRL;} OPERATION; RECOVERY.

(Under the care of Mr. ExICHSEx.)

W $\mathrm{x}$ have endeavoured from time to time, as opportunities permitted, to bring the subject of excision of the hip-joint be fore the profession in our "Mirror," for the purpose of fairly estimating its value as a conservative measure, and drawing a comparison between it and excision of other joints. From the valuable series of cases which have appeared in our pages since the beginning of last year, the conclusion has been justly arrived at, that excision of the hip-joint is not only suitable when the head of the femur is diseased, acting as a foreign body, and keeping up a constant irritation, but that it is justifiable even when the pelvis is more or less affected, and that the portions of the latter in a state of necrosis or caries require to be taken away also, (THE LANCET, vol. i. 1857, p. 141 vol. ii. 1857 , pp. $339,362,390$, and 417 ; vol. i. 1858 , p. 118.) In fine, in almost any case of disease of the articulation generally, in which an exhausting suppuration is the result of necrosis of the pelvis or the femur, it is the duty of the surgeon to get rid of the effete and dead portions of bone. Mr. Han. cock, we may say, first paved the way in setting aside the prejudices of surgeons against the operation when there was disease of the pelvic bones, and the success obtained by himself and subsequently by others, in the good results attending the removal of pretty extensive portions of the pelvis, is a fair guarantee of the propriety of the proceeding. In $\mathrm{Mr}_{\text {。 }}$ Han 